\title{
THE IMPACT OF RISK MANAGEMENT ON FINANCIAL PERFORMANCE
}

\author{
Bilal Toufaili \\ Lebanese International University, Beirut, Lebanon
}

Commercial banks that control a large proportion of overall assets of the financial sector primarily rely on extending credits, and banks may raise their earnings through this function which constitutes one of the major functions of commercial banks.

Consequently, and due to the wide multiple risk exposures of commercial banks, the issue of capital structure has become a vital element in determining the viability of banks and their ability to withstand various risks involved. Hence, risk management as such has become an essential part of evaluating various risks, including credit risks, liquidity risks, solvency risks and so forth.

It is necessary to remember that banks differ from one to another in many respects, namely, their goals, services and strategies. Thus, banks are facing various risks in their day-to-day operations.

The research here has implemented a quantitative methodology throughout distributing a survey over a defined number of respondents, and the results were viewed through the prism of regression analysis and Pearson correlations. The obtained results prove there is a direct relationship between market risk, liquidity risk, credit risk, and solvency risk. The results also prove that the higher the risk management ratios are managed, the higher the net income will be.

Keywords: net income; credit risk; market risk; solvency risk; liquidity risk; financial performance; banking sector

\section{Introduction and Background Overview}

Commercial banks that control a large proportion of the overall assets of the financial sector primarily rely on extending credits (Abel, 2016). Banks may raise their earnings through this function which constitutes one of the major functions of commercial banks.

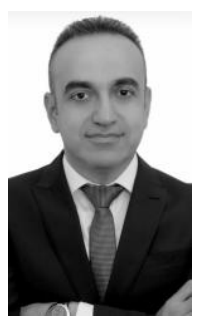

\section{Bilal Toufaili}

$\mathrm{PhD}$ in BusinessAdministration - Management Concentration Lecturer in Lebanese International University, Beirut, Lebanon Research Interest: leadership in management, impact of risk management on organizational performance 


\section{THE IMPACT OF RISK MANAGEMENT}

It is necessary to remember though that banks vary from one to another in many respects, in particular, their goals, services and strategies. In fact, banks face various risks in their day-to-day operations.

So bearing in mind these risks, markets are affecting the profitability of commercial banks as it was, for example, in the case of Thailand in the mid of 1997, where the Asian financial crisis contributed to a major currency depreciation, falling share values and thus to political and economic turmoil.

Other examples include Asian emerging markets' stock crash that have also affected banks, namely in the Philippines. This country faced a drop of $49 \%$ in its stock exchange along with Thailand (Alqisie, 2018).

Later on, with the global financial crises of the 1980s and the 1990s, contemporary risk control banking strategies (Goddard, 2004) started to be gradually implemented, especially after the most recent global financial crisis (GFC).

As the economic development in different countries deteriorated at the start of 1997 , the bank-related risk factors became acute. In case of commercial banks specifically, credit risks remained to be one of the topics of interest, for both academia and practitioners in the banking field.

Credit risk as such is defined as the probability of a situation when different parties refuse to satisfy their commitments according to the in advance negotiated conditions. It is a risk of capital loss for which the funds that are lent by banks in the form of loans was not reimbursed, i.e., this is the risk of default in payments.

Similarly, credit risk is defined by (Hallunovi, 2018) as the likelihood that debtors will not pay the principal and/or the interest owed on the debt.

\section{Significance of the study}

Risk management is one of the major concerns for senior managers who are in charge of high positions in banks since they consider risk management as the future of the banking industry. Therefore, it should be addressed in the most effective and efficient manner.

Yet, in recent years, commercial banks have been facing problems due to a variety of sources and their origins. The key factors include the following:

- loosening credit requirements

- inadequate risk control over portfolios.

Many commercial banks have actually authorized loans without proper due diligence examination, and this fact has also contributed to a rise in a number of defaults on loans and non-performing loans.

Furthermore, the present risk control techniques are contended to be inadequate while copying with the emerging credit risk issues.

Collapse of any large bank has an important effect on the economy of a nation in which the banking system is regulated by a central bank. This is because any failure that could arise in the sector will result in bank defaults and general financial instability and economic tribulations (Kithinji, 2010).

Accordingly, the commercial banking sector should ensure that successful policies are implemented in order to reduce the number of related risks and also to optimize their financial returns and maintain successful operations to preserve their liabilities along with their equity. 


\section{Financial Risks and Financial Performance}

Credit risk, liquidity risk and market risk as constituents of the financial risk together affect financial performance and volatility.

Bank performance overall is highly affected by credit risk since the latter leads to the possibility that the total value of assets may change in value because some counterparty has failed to meet its commitments under the contracted liability (Li, 2014).

The volatility of interest rate risk is the possibility of a fluctuation in the cost of loans or deposits (Li, 2014). If the interest rate of a commercial bank loan is less than the cost of the deposit, or if it is higher than the market rate or if the interest rate on a deposit is higher than the market rate, it may present a risk to a bank's interest rate. At this stage the bank draws the GAP Analysis and the Maturity Buckets.

On the other hand, the currency risk is linked to the domestic currency depreciation, price variations and output drops. If a bank does not hedge by selling and/or buying foreign currency at a fair price, or if the foreign currency steadily depreciates in value, the bank is subject to a grave exposure that might lead to a default situation.

Besides analyzing the risk exposures, profitability remains to be a major concern for banks as well as for their shareholders.

Therefore, information related to the bank's ability to broaden its operations belongs to the targets of the board of directors. Certain ratios in this regard provide an upfront indication of banks' profitability such as:

- ROE (net income/equity),

- ROA (net income/total assets) and

- debt ratio (equity/total assets)

These are some of the key measures used to improve bank productivity (Saeed \& Zahid, 2016).

Comparisons of crucial profitability metrics, such as returns on investment and equity returns to the standards (Sun \& Chang, 2018), are the main ways of profitability assessment. Regardless of the terms accepted, bank capital is also widely used for assessing its financial strength.

Solvency of financial institutions is increasingly at risk as their assets become deteriorated. This leads to the over-exposure to specific risk patterns in non-performing loans. Security and viability of bank lenders are also essential part of quality metrics monitoring.

In addition to all of the above, financial risk and financial performance, that are linked to loan portfolio which might become default on the creditor side, can lead to cash flow problems, thus ultimately affecting the liquidity position of a bank.

Sayilgan (2009) analyzed the period between 1996 and 2005, and the relationship between financial risk and competitiveness of traditional and Islamic banks in Malaysia. Their analysis was based on the use of the generalized least squares method with the panel data regression of fixed effects and random impact models. The authors found that loan vulnerability significantly affects the profitability of both traditional and Islamic banks.

Although financial risk directly impacts financial performance, in any analysis of financial success the return on assets and the return on equity are crucial measurements to be adopted. Moreover, many researchers have performed simultaneous measurements by using the instrument of regression vectors to set the outcome in two-stage lower squares. 


\section{THE IMPACT OF RISK MANAGEMENT}

The results showed that both ROA and ROE are critical in the use of data. Moreover, the results also showed that regulatory and financial relationships cannot be halted and that commercial banks and banking managers try hard to find a proper balance between risks and financial performance.

Another aspect in the relationship between financial risk and financial performance was demonstrated by Shijaku (2017) who studied the relationship between financial risk and performance of Islamic banking institutions in the Gulf Cooperation Council countries. The author collected data between 2000 and 2012, on 11 of the 47 Islamic banks in the GCC region. ROA and ROE were used as the main measure for determining bank performance.

On the other hand, the following risks were also considered and taken into account:

- credit risk,

- liquidity risk

- $\quad$ and operating risk.

The regression analysis revealed there is a significant negative relationship between Islamic banks ' efficiency, equity and operating risk. The findings have reaffirmed the existence of a significant negative relationship between the economic success of the Gulf Cooperation Council overall and the Islamic banks. Capital risk and operational ris were found to be the most significant types of risks in that study.

\section{Credit Risk and Financial Performance}

Credit risks constitute the most significant group of risks that banks are subject to. And the success of banks in prevention and fighting credit risk depends greatly on accurate measurement and successful risk management (Alqisie, 2018).

Olajide \& Fadun (2017) analyzed four Swedish banks across the period from 2000 to 2008, concentrating on the relationship between:

- declining credit

- capital adequacy ratios and

- productivity.

Their study showed that the prevalence of non-performing loan levels, while their degrees differ from bank to bank, is reciprocally linked to ROE.

Olalere \& Wan (2016) conducted another study on the bank's loan activity of commercial banks in Turkey with the sample of 18 banks. Some inverse relationships between performance, efficiency and credit risk indicators were identified in this study. Identifying the determinants of bank lending activity was the primary purpose of this research. The data covered the period from 2003 to 2012, and the variables used included:

- long-term exposure to capital,

- interest rates,

- GDP growth and

- inflation.

The investigation resulted in finding a significant positive effect on banks ' investor behavior, exposure to long-term credit and inflation rate, but interest rates and GDP remained to be rather negligible in their effect.

The impact of lending-to-performing loans and advances on outstanding assets on overall assets was evaluated back in 2010 by Kithinji (2010). They also measured the effect of credit risk calculated from the loan and advance ratio between 2004 and 2008 on the total assets of Kenyan banks. The study found that commercial banks' bulk earnings are not 
impacted by the volume of credit and non-performing loans. The earnings of trade banks fluctuated over the decade but rose slightly on average between 2004 and 2008. The income during the study period was generally low. The credit to consumers was relatively high, but the trend over the time span was downward.

The effect on the competitiveness of banks in Ghana was examined by Olokoyo (2011). Their research evaluated ten rural banks ' financial statements, 2006 to 2010. For estimations, the panel regression model was used. Return on Equity (ROE) and Return on Asset (ROA) were used as the measures of productivity. In contrast, the ratio of nonperforming loans (NPL) and capital adequacy ratio (CAR) were used as the indicators of credit risk management. The results showed a significant positive correlation between nonperforming loans and the competitiveness of rural banks, suggesting that there are more significant losses from loans but that there are still benefits for banks.

Olusanmi et al. (2015) later noted that the credit risk control over individuals carried out by rural banks is related to the competitiveness of Ghana as an economy. Higher capital adequacy demonstrated by rural banks can lead to better advance loans and absorb loans as they expand while increasing productivity. The findings of Olusanmi et al. (2015) also confirmed there is a relationship between credit risk control and performance. However, financial performance of banks can be influenced by other factors such as:

- low income,

- $\quad$ exposure to structured services and

- the lack of information and understanding in general.

Credit risk and its impact on the competitiveness of Nigerian banks were also analyzed by Saeed \& Zaheed (2016). Financial ratios such as bank efficiency and credit risk indicators were gathered and evaluated using descriptive, correlation and regression methods applied to the data from the 2004-2008 annual reports and accounts of the addressed banks. The results showed that credit risk management has an essential impact on Nigerian banks' profitability. Thus, the author concluded that competitiveness of banks in Nigeria is affected by credit risk management practices.

Credit risk's systematic impact on the profitability of commercial banks in Nigeria over the period of eleven years (2000-2010) was also analyzed by Sun \& Chang (2018) who used the panel model methodology. Their results demonstrated that credit risk has a crosssectional effect on banks' profitability calculated as bank returns on assets.

Therefore, besides already traditional ROE and ROA, the main ratios to be used to determine credit risk could be as follows:

- $\quad$ non-performing loans to total assets (NPL/LA) ratio

- $\quad$ net advances \& loans to total deposits (LA/TD) ratio

- loan loss allowance to classified loans (LLP/CL) ratio.

Sayilgan (2009) also discussed various parameters related to credit risk management. In his analysis, the following criteria were included:

- default rates

- loan expenses

- capital adequacy.

In the 11 years (2001 to 2011) 31 banks ' financial reports were analyzed as secondary data to determine the relation between the return on default, loan cost assets and equity ratio. The results of that study showed that each of these parameters had an inverse effect on banks' financial performance. It was then evaluated using correlation and regression models. 


\section{THE IMPACT OF RISK MANAGEMENT}

The research found that substantial adverse relationships exist between the default rate and the capital adequacy ratio, between return on assets and an independent variable. The results also showed an adverse relationship since the capital adequacy coefficient was -0.125 which means it adversely affects the profitability ratios by $12.5 \%$.

Shijaku (2017) investigated the impact of credit risk management determinants on the financial performance of commercial banks. This author tried to determine whether there was a correlation between credit risk management (CAMEL metrics applied) and the financial results of commercial banks in Kenya. The Central Bank of Kenya's survey results were used for this along with the banks' own financial statements, accompanied by secondary evidence data.

The time frame of this study was 2006 to 2010, and a causal study approach was applied. The approach used for data analysis was based on Pearson's correlation analysis and a multiple regression model. The study found that the financial performance of commercial banks in Kenya is strongly affected by the components of CAMEL.

The study also showed that capital adequacy, asset consistency, capacity of management and liquidity is low in comparison to the financial performance (measured by ROE). Thus, the study concluded that the CAMEL model can be used as a tool for controlling credit risk. Also, the study found the liquidity ratio coefficient to be at -0.401 which means it tends to affect the profitability by $40.1 \%$.

\section{Market Risk and Financial Performance}

For financial institutions market risk is a primary cause of profit volatility. Market risk generally consists of the three types of risks:

- stock price risk

- interest-rate risk

- exchange risk.

Alqisie (2018) also noted that when banks consider financial instruments which are exposed to price volatility as security for loans, this type of market risk arises as a guarantee.

Business risks may be divided into the risk of exchange rates and the risk of the interest rates, including the risk of gold, share price risks, and the risk of commodity prices, which are linked to the risks related to fluctuations in exchange rate and market price levels.

Supporting the logic above, Hallunovi (2018) carried out a study to find out the market risk control strategies and their appropriateness for commercial banks in Kenya in the context of reducing financial losses. A census sample was the key research method implemented in that study. The population consisted of 43 commercial banks approved by the Central Bank of Kenya. The results of the study revealed that scenario analysis and stress testing were very much the key strategies employed by the banks in question. Securities mark-to-market were also used but to some degree only. Given the results above, the risk mitigation coefficient was -0.291 which means it tends to affect the financial performance by $29.1 \%$.

Thus, Kenya's banks need to define their best practices in order to monitor market risk exposure and thus to reduce the impact of losses caused by this type of risk. The analysis was based on primary data only, without balance sheet metrics, to show the effect of market risk. This study varied from many previous studies which had analyzed the effect of market risk on financial performance using financial metrics in the first place.

Competitiveness of THE selected financial institutions in Sri Lanka, 2007 to 2011, was investigated by Kithinji (2010). Systematic risk management was the independent variable in 
their study, and performance (measured through net profit, return on capital employed (ROCE) and return on capital (ROE)) was the dependent variable.

The analysis also involved calculations for the degree of financial leverage (DFL) and degree of operational leverage (DOL). Secondary data sources were also used for the analysis, and the findings reported that systemic risk management had a positive association with competitiveness $(\mathrm{r}=0.755, \mathrm{p}<0.05)$. The analysis also showed that DFL and DOL boost the systemic risk control in the selected financial institutions, whereas positive effects on productivity are identified. DFL and DOL were used in this study as two different factors to assess productivity impacts.

Finally, Olajide \& Fadun (2017) analyzed the degree of debt and the degree of financial leverage in the USA. The author explored the connection between business uncertainty and relative valuation. The study showed there is a beneficial influence upon the valuation of operations and financial leverage of the firm, thus suggesting that the value of a company improves with the raise of benefit debt. The analysis also revealed that excess returns were favorable and enhanced by the debt, the financial leverage, and the structural risk to the firms in the sample, thus showing a positive link between retail revenues and returns.

\section{Methodology}

\section{Population}

39 commercial banks are our population. The survey method was used in relation to all licensed commercial banks to make sure that the data available for this study is both accurate and effective.

At the same time, we have also implemented the quantitative methodology by distributing the survey template to over 200 interviewees within the Banque Libano-Francais network (based in Lebanon). Only 123 interviewees replied to our questionnaires.

\section{Data Collection}

Secondary statistics have been obtained from the annual reports of Banque LibanoFrancaise. It includes certain ratios of interest for us, namely, the most utilized ones such as ROE (which would be the dependent variable in our further calculations) as a unit of measuring banks' financial performance.

\section{Data Analysis}

The purpose of our research has been to analyze the following:

- the relationships,

- the differences,

- $\quad$ the trends and

- $\quad$ the comparisons.

The data collected (and then organized in tables) serves to describe and assess the effect of risk management on commercial banks ' financial performance as far as earnings are concerned .

As already noted above, quantitative data have been used in this study. 


\section{THE IMPACT OF RISK MANAGEMENT}

Our research stemmed from the quantitative methodology while distributing the survey over a number of respondents for data collection purposes. Afterwards, for analyzing the collected data the SPSS statistical tool has been applied.

The survey has been constructed based on the Likert scale (1 - Strongly Agree, 2 Agree, 3 - Neutral, 4 - Disagree, and 5 - Strongly Disagree). The questionnaire has been constructed based on the independent variables under investigation.

The dependent variable is ROE outcome of the addressed bank network.

Once the regression analysis has been concluded, the results have been additionally tested to validate the research hypothesis. If the significance level is below 5\%, then $\mathrm{H} 0$ is rejected and $\mathrm{H} 1$ is accepted, and vice versa.

\section{Analytical Model}

Regression analysis was thus used to determine the effect of risk management on financial performance, measured through ROE of the selected commercial banks in Lebanon.

The relationship equation presented as a formula below indicates the target and the purpose of the regression:

$$
\mathrm{ROE}=\alpha+\beta \text { Credit Risk }+\beta \text { Market Risk }+\beta \text { Liquidity Risk }+\beta \text { Solvency Risk }
$$

Thus, the following hypotheses will be tested further:

H10: There is no relationship between credit risk and financial performance.

H11: There is a relationship between credit risk and financial performance.

$\mathrm{H} 20$ : There is no relationship between market risk and financial performance.

$\mathrm{H} 21$ : There is a relationship between market risk and financial performance.

\section{Testing the Significance}

The relevance of the experiment has been calculated through variance analysis (ANOVA), with a $95 \%$ confidence interval, and a $5 \%$ significance. The value of the sample was established. Changed $\mathrm{R}$ square was used to assess the contingent variable volatility because of the shifts in the independent variables under investigation.

\section{Findings}

\section{Solvency Risk Descriptive Statistics}

Further, we address the descriptive statistics for the solvency risk variable. The $\mathrm{N}$ value in the table above corresponds to the number of the addressed banks in our research study. In other words, we had 123 respondents from a network of commercial banks.

The minimum and maximum values in our analysis correspond to the Likert scale used, ranging from 1 to 5 and corresponding accordingly to Strongly Agree (as coded in SPSS) and to Strongly Disagree (also coded in SPSS).

As for the mean, this outcome corresponds to the average of the respondents' answers. However, the results actually show that the mean of the respondents' answers is around 2.201. This value falls under the Agree scale according to the initial research scale.

The respondents had the mean of 2.18 and 2.08. This assumes they agree that the banks tend to identify risks, and accordingly, aim to prioritize their main risk changes as per banks' roles and responsibilities. 
Table 1 - Solvency Risk Statistics

(calculated by the author)

\begin{tabular}{|c|c|c|c|c|c|}
\hline & Z & $\stackrel{\Xi}{\Xi}$ & 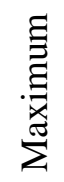 & 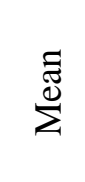 & 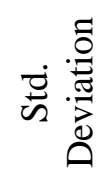 \\
\hline $\begin{array}{l}\text { The bank carries out a compressive and } \\
\text { systematic identification of its risks relating } \\
\text { to each of its declared aims and objectives }\end{array}$ & 123 & 1 & 5 & 2.18 & 1.124 \\
\hline $\begin{array}{l}\text { The bank finds it difficult to prioritize its } \\
\text { main risk }\end{array}$ & 123 & 1 & 5 & 2.08 & 1.083 \\
\hline $\begin{array}{l}\text { Changes in risks are recognized and } \\
\text { identified within roles and responsibilities } \\
\text { established in a bank }\end{array}$ & 123 & 1 & 5 & 1.98 & 1.075 \\
\hline $\begin{array}{l}\text { The bank is aware of the strengths and } \\
\text { weaknesses of risk management systems in } \\
\text { other banks }\end{array}$ & 123 & 1 & 5 & 2.04 & 1.155 \\
\hline $\begin{array}{l}\text { The bank has developed and applied } \\
\text { procedures for systematic identification of } \\
\text { opportunities }\end{array}$ & 123 & 1 & 5 & 2.77 & 1.311 \\
\hline $\begin{array}{l}\text { It is crucial for the bank to apply the most } \\
\text { sophisticated techniques for risk } \\
\text { identification }\end{array}$ & 123 & 1 & 5 & 2.16 & 1.003 \\
\hline Valid N (listwise) & \multicolumn{5}{|c|}{123} \\
\hline
\end{tabular}

However, other respondents had their answers with the mean of 2.04 and 2.77. This assumes they strongly agree that the solvency risk practices are implemented in the banks under investigation and that commercial banks in Lebanon are aware of the strengths and weaknesses of the risk management systems implemented and that they are willing to apply the most sophisticated techniques to identify risks.

Still, the average of the means mentioned in the table came out to be 2.0. This means that the respondents agree that managing solvency risks tends to impact the financial performance of commercial banks: the higher is the solvency risk, the better the ROE of banks will be.

Generally speaking, this means that commercial banks are actively introducing solvency risk practices to maintain high financial performance. 


\section{THE IMPACT OF RISK MANAGEMENT}

Table 2 - Market Risk

(calculated by the author)

\begin{tabular}{|c|c|c|c|c|c|}
\hline & Z & 刍 & $\stackrel{\Xi}{\Xi}$ & 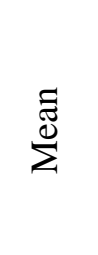 & 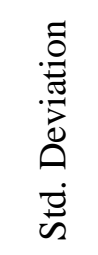 \\
\hline $\begin{array}{l}\text { Monitoring the effectiveness of risk management is } \\
\text { an integral part of the routine management } \\
\text { reporting }\end{array}$ & 123 & 1 & 5 & 1.95 & .965 \\
\hline $\begin{array}{l}\text { The level of control by the bank is appropriate to } \\
\text { the risks it is facing }\end{array}$ & 123 & 1 & 5 & 2.37 & 1.162 \\
\hline $\begin{array}{l}\text { The bank has adopted a standard reporting system } \\
\text { about the risk management, from bottom to top } \\
\text { management }\end{array}$ & 123 & 1 & 5 & 1.52 & 853 \\
\hline $\begin{array}{l}\text { Reporting and communication processes within the } \\
\text { bank support the effective management of risks }\end{array}$ & 123 & 1 & 5 & 1.71 & .885 \\
\hline $\begin{array}{l}\text { The bank's response to risks includes evaluation of } \\
\text { the effectiveness of the existing controls and risk } \\
\text { management }\end{array}$ & 123 & 1 & 5 & 1.55 & .715 \\
\hline $\begin{array}{l}\text { The bank's response to risk includes action plans } \\
\text { aimed at implementation of decisions concerning } \\
\text { identified risks }\end{array}$ & 123 & 1 & 5 & 2.33 & 1.272 \\
\hline $\begin{array}{l}\text { The bank effectively monitors the credit limit for } \\
\text { each counterparty }\end{array}$ & 123 & 1 & 5 & 2.14 & 1.393 \\
\hline $\begin{array}{l}\text { The bank reviews the country ratings on a regular } \\
\text { basis for its international financing } \& \text { investment } \\
\text { purposes }\end{array}$ & 123 & 1 & 5 & 2.52 & 1.244 \\
\hline $\begin{array}{l}\text { The borrower's business performance is regularly } \\
\text { observed by the bank, following the extension of } \\
\text { financing }\end{array}$ & 123 & 1 & 5 & 1.99 & 1.075 \\
\hline Valid N (listwise) & 123 & & & & \\
\hline
\end{tabular}

\section{Market Risk Statistics}

The following section addresses the descriptive statistics of the market risk variable, and our results show that the mean of the respondents' answers falls between 1 and 2 which falls under the Agree and Strongly Agree categories on the scale.

Furthermore, referring to the above results, the market risk tends to affect ROE and ROA of the banks in a negative way, meaning that if the market risk is high, then ROE tends to be affected in a negative way, and vice versa.

However, the mean of the addressed results is 2.01 which means that most of the respondents agree that the market risk impacts the financial performance of commercial banks in Lebanon.

For example, let's take the current case: now the country is suffering from the foreign exchange rate that is pegged at 1520 versus the black market. This is obviously a market risk, 
and the banks in Lebanon are working on managing this risk by blocking check deposits, and also by reducing the number of loans granted to local customers.

\section{Regression Analysis}

The model summary (see Table 3) explains the relationship among the dependent and the independent variables using various indicators in which $\mathrm{R}$ constitutes $62.8 \%$, meaning that about $37.2 \%$ of the variables tend to affect the financial performance of the studied banks.

As for R-Square, it shows the strength of the relationship among the variables. Its value of $39.4 \%$ means that liquidity risk, risk control and credit risk tend to impact $39.4 \%$ the financial performance of the investigated banks.

Table 3 - Regression Analysis

(calculated by the author)

\begin{tabular}{|c|c|c|c|c|c|c|c|}
\hline \multicolumn{6}{|c|}{ Model Summary } & & \\
\hline Model & $\mathrm{R}$ & $\begin{array}{c}\mathrm{R} \\
\text { Square }\end{array}$ & $\begin{array}{l}\text { Adjusted R } \\
\text { Square }\end{array}$ & \multicolumn{2}{|c|}{$\begin{array}{l}\text { Std. Error of the } \\
\text { Estimate }\end{array}$} & & \\
\hline 1 & $0.628 \mathrm{a}$ & 0.394 & 0.374 & \multicolumn{2}{|c|}{0.02285} & & \\
\hline \multicolumn{8}{|c|}{ a. Predictors: (Constant), Market Risk, Credit Risk. } \\
\hline \multicolumn{8}{|c|}{$\begin{array}{ll} & \text { Coefficients } \\
\end{array}$} \\
\hline \multirow[t]{2}{*}{ Model } & & & \multicolumn{2}{|c|}{$\begin{array}{l}\text { Unstandardized } \\
\text { Coefficients }\end{array}$} & $\begin{array}{c}\text { Standardized } \\
\text { Coefficients }\end{array}$ & \multirow[t]{2}{*}{$\mathrm{T}$} & \multirow[t]{2}{*}{ Sig. } \\
\hline & & & $\mathrm{B}$ & Std. Error & & & \\
\hline \multirow{3}{*}{1} & (Constant) & & 0.017 & 0.010 & & 1.744 & 0.085 \\
\hline & Market Risk & & 0.427 & 0.117 & & 3.656 & 0.010 \\
\hline & Credit Risk & & 0.239 & 0.098 & & 2.449 & 0.016 \\
\hline
\end{tabular}

Lastly, standard deviation is around $2 \%$ which indicates a good normality distribution and also that the data does not contain any bias.

Hence, referring to the above regression analysis, there is a direct relationship between the dependent and the independent variables, with a significance error of 5\%. The results show a significance level lower than $5 \%$, meaning that there is a correlation between the independent variables being as follows:

- $\quad$ solvency risk (0.023),

- market risk (0.010),

- $\quad$ credit risk (0.016),

- liquidity risk (0.016)

- towards the financial performance of the banks.

Thus, the following can be concluded overall:

Financial Performance $=0.085+0.010$ market risk +0.016 credit risk +0.047 liquidity risk +0.023 solvency risk 


\section{THE IMPACT OF RISK MANAGEMENT}

These figures can be interpreted as follows:

1) For every one-unit increase in the market risk, the performance of ROE is affected by $1 \%$ in a positive way, since the coefficient of the regression analysis is positive, meaning that this is a proportional relationship between market risk and financial performance. Hence, the higher the market risk is managed, the better the financial performance of the bank will be as reflected in ROE.

2) For every one-unit increase in credit risk, the performance is affected by $1.6 \%$.

3) For every one-unit increase in liquidity risk, the performance is affected by $4.7 \%$.

4) For every one-unit increase in solvency risk, the performance is affected by $2.3 \%$.

Now it's turn for the T-test, which is another method to validate the research hypotheses. It can be calculated by dividing Beta / Standard Error, and in our specific case it can be explained as follows:

1) Solvency risk: $0.426 / 0.118=3.610$, which means that solvency risk tends to impact financial performance by $3.6 \%$.

2) Market Risk: $0.427 / 0.117=3.656$, meaning that market risk tends to impact financial performance by $3.65 \%$.

3) Credit Risk: $0.239 / 0.098=2.449$, meaning that credit risk tends to affect ROE of the bank by $2.49 \%$.

4) Liquidity risk: $0.273 / 0.094=2.904$, meaning that liquidity risk tends to impact ROE of the bank by $2.90 \%$.

Table 4 - Pearson Correlation Analysis (calculated by the author)

\begin{tabular}{|c|c|c|}
\hline \multirow{2}{*}{$\begin{array}{c} \\
\text { Solvency } \\
\text { Risk }\end{array}$} & Pearson Correlation & Financial Performance \\
\cline { 2 - 3 } & Sig. (2-tailed) & .172 \\
\cline { 2 - 3 } & $\mathrm{N}$ & .094 \\
\hline \multirow{3}{*}{ Market Risk } & Pearson Correlation & 123 \\
\cline { 2 - 3 } & Sig. (2-tailed) & .086 \\
\cline { 2 - 3 } & $\mathrm{N}$ & .403 \\
\hline
\end{tabular}

Pearson correlations analysis is an inferential statistical test which aims to study whether the relationship between research variables is positive or negative, based on the indicator known as Pearson Coefficient. If this indicator shows a positive sign, then the relationship is a proportional one; and if the Pearson coefficient shows a negative sign, then the relationship is of an inverse nature.

As for the $\mathrm{N}$ indicator, it represents the sample.

In our case, the Pearson test shows that the results related to solvency risk impact financial performance in a positive way, if it is well managed, meaning that the solvency risk impacts financial performance by $17.2 \%$.

Furthermore, the results prove that market risk tends to impact financial performance by $8.6 \%$, if it is well managed. Thus, the better the management is implemented as for market risk, the better the financial performance of a bank will be. 
Hence, based on the collected data and based on Pearson Correlations the Solvency Risk is the highest risk that might impact the financial performance of the bank.

Validity and Reliability Analysis

Table 5 - Component Matrix

(calculated by the author)

\begin{tabular}{|c|c|}
\hline & Component \\
\cline { 2 - 2 } & 1 \\
\hline Performance & 0.804 \\
\hline Market Risk & 0.791 \\
\hline Solvency Risk & 0.704 \\
\hline
\end{tabular}

Table 5 above explains validity and reliability of the collected data based on the indicator called Cronbach alpha.

The validity and reliability test aims to show whether the collected data are valid or not indicating a Cronbach Alpha above the level of 0.7.

However, the rule of thumb is as follows:

- Cronbach Alpha below 0.5 means that data is invalid and not reliable.

- Cronbach Alpha between 0.5 and 0.7 means that data is valid but contains bias.

- Cronbach Alpha above 0.7 means that data is valid and ready for statistical analysis.

Henceforth, the following can be summarized from our table data and the findings obtained:

- Performance has a Cronbach alpha of 0.804 (above 0.7) which means that the data collected from the respondents in the bank is valid and reliable.

- Market Risk has a Cronbach Alpha of 0.791 (above 0.7) which means that the data collected from the respondents in the bank is valid and reliable.

- Solvency Risk has a Cronbach Alpha of 0.704 (above 0.7) which means that the data collected from the respondents in the bank is valid and reliable.

\section{Summary of the Key Findings}

Our findings show that minimizing risk tends to impact the financial performance of commercial banks in Lebanon as explained by the regression and Pearson correlation analysis.

This factor has been addressed profoundly throughout many of the previous studies related to risk management practices including credit risk, market risk, solvency risk and liquidity risk. The findings of our study also reveal some major challenges in strengthening the overall activities of commercial banks that are trying to reduce risk.

Furthermore, the findings have been evaluated through quantitative data analysis that provided valuable analytical knowledge. The research proves that managing credit risk, 


\section{THE IMPACT OF RISK MANAGEMENT}

liquidity risk, market risk and solvency risk tend to impact the financial performance of the bank in a positive way, since minimizing risks enhances ROE of banks, thus boosting financial performance and profits.

A relation is widely agreed upon between risk management programs and banks performance, particularly ROA and ROE, both indicating the profitability of banks.

Consequently, the analysis shows the greater the amount of net income (year-on-year) by utilizing

- $\quad$ stress tests and

- credit scoring

- for example, to calculate their credit risk exposure, would enhance the earnings over time.

These results suggest that commercial banks should use the tools available to them to recognize a broader variety of variables and criteria that can influence their financial viability.

Also, commercial banks became more involved in evaluating their vulnerability to credit risk when branch managers are using scoring techniques that untimely raise their annual return on equity.

In addition, the findings show that inspection by branch managers has been generally an active credit risk evaluation technique with a positive effect for banks' financial sustainability.

Furthermore, the findings show that a substantial correlation exists between the credit risk assessment policy of a commercial bank and its ROE/profitability as proved by our regression analysis. Yet, the more financial firms increase their loans, the more vulnerable they become to credit risk. This result suggests it is imperative to apply the strategy of exposure limits in order to preserve banks' profitability.

Interestingly, our study has been also successful in statistically linking the exposure limit strategy of commercial banks on the one hand and profitability on the other. It is thus fair to assume that the more exposure limits are applied towards future credit threats, the more successful a commercial bank would be.

However, risk management and recognition of risks as such both have a strong influence on commercial banks' performance results. Yet, for risk estimation and risk monitoring purposes, the researchers make their decisions based on the provided tools while detection of risks goes as secondary.

The usage of credit risk estimation techniques includes the following:

- financial statement analysis,

- credit score analysis,

- creditworthiness analysis,

- credit ranking and

- models of credit portfolios,

All of them are necessary to apply in order to retain and improve the profitability of commercial banks. 


\section{Recommendations and Future Prospects}

Our study has analyzed the effect of risk management practices towards financial performance of commercial banks in Lebanon using ROE as the indicator which should be applicable to other commercial banks as well.

The research recommends implementing new variables other than the ones already used in this research, in addition to implementation of both quantitative and qualitative methodologies to enhance the quality of the research and study the viewpoints of both managers and employees.

The research also recommends carrying out a comparative study between commercial national banks and foreign banks in order to understand how risk management practices can be further improved.

Normally, banks clarify the risk-measuring approaches they are implementing; yet, it remains to be the fact that they should implement more technological and reliable methods to better handle the financial risk which is getting increasingly graver under the current situation.

Further recommendations to commercial banks are related to validating and streamlining their risk control plans, processes and activities in line with the global trends towards Basel III. Financial institutions should follow these principles and be able to compare their risk control processes and activities on an international scale.

Concerning budget distribution, banks should ensure that their risk control has an independent budget and also ascertain that funds are expensed to mitigate the evolving risk climate. Banks' risk departments must be able to handle the increasing financial risks effectively, thus boosting their financial efficiency.

Additionally, credit officers in banks must be subject to training programs that would enable them to assess diligently the creditworthiness of clients prior to providing any loans. It is important to adequately train credit officers, and then the probability of defaults attributable to inadequate appraisal of loan applicants would be minimized.

Further, banks' management must establish a credit risk management program aimed at awarding current loans while significantly reducing the acceptance of credits that have the potential to become problematic or lose in the long run by applying the IFRS 9 techniques. The risks related to supplying untrustworthy borrowers with credit facility are significantly minimized by such a strategy.

To sum up, management in commercial banks must continuously improve employee's awareness about credit risk management and its enforcement requirements. In other words, commercial banks must inform their staff, credit officers in particular, of the need to comply with the regulations, thus ensuring banks' continued activity.

At the final stage of our recommendations, an attempt is made to prove the viability of the hypothesis, in which the values of the studied variables are applied to prove the extent of performance improvement.

Given that the net income of the studied bank network were

- USD 120,037,000 in 2017 and

- $\quad$ USD $121,440,000$ in 2018 


\section{THE IMPACT OF RISK MANAGEMENT}

and given that according to our regression analysis, net performance will be affected by the selected variables, then the following calculations are made to validate the effect of the regression outcome, based on the 2018 net income alone:

1) Solvency risk: impacts the financial performance by $3.6 \%$ and less $37.2 \%$ as noted by the R-model summary, then the adjustment factor should read as $2.261 \%$.

Accordingly, the 2018 net income should be read as $\$ 121,440,000 \times 1.0226=\$$ $2,745,758$ to become $\$ 124,185,758$ if the recommendations are applied.

2) Market Risk: impacts the financial performance by $3.65 \%$ and less $37.2 \%$ as noted by the R-model summary, then the adjustment factor should read as $2.302 \%$.

Accordingly, the 2018 net income should be read as $\$ 121,440,000 \times 1.023=\$$ $2,795,549$ to become $\$ 124,235,548$ if the recommendations are applied.

Henceforth, it can be concluded that the risk ratios play an important role since they are affecting the financial performance of commercial banks in Lebanon. If all of the noted risks were taken care of, then local commercial banks would have demonstrated a $7.9 \%$ growth to their actual 2018 net income.

Our very final conclusion is that under the present recession and the default risks that the country is facing from the treasury bills and other securities and also because of the doubtful advances and loans increasing in number, all commercial banks should increase their equity and apply risk management tools as described in this research.

\section{References:}

Abel, S. (2016). Determinants of Banking Sector Profitability in Zimbabwe. International Journal of Economics and Financial Issues, 6 (3), 845-854.

Alqisie, A. (2018). Impact of Risk Management on Profitability. European Journal of Scientific Research, 143(3), 319-332.

Goddard, J. (2004). The Profitability of European Banks. The Manchester School, 72 (3), 363-381.

Hallunovi, A. (2018). The Relationship Between Risk Management and Profitability of Commercial Banks in Albania. Asian Themes in Social Sciences Research, 1(2), 44-49.

Kithinji, A.M. (2010). Credit Risk Management and Profitability of Commercial Banks in Kenya. School of Business, University of Nairobi.

Li, F. (2014). Impact of Risk Management on Profitability of Commercial Banks. Umea School of Business and Economics.

Olajide, S. F., \& Fadun, O. (2017). Corporate governance, a risk management tool for enhancing organizational performance: Study of Nigeria Stock Exchange (NSE) listed companies. International Journal of Finance \& Banking Studies, 6(4), 12-27.

Olalere, O. E., \& Wan, A. B. (2016). Risk management and the financial performance of commercial banks in Nigeria: A literature review revisited. Journal of Economics and Finance, 7(2), 14-19.

Olokoyo, F. O. (2011). Determinants of commercial banks' lending behaviour in Nigeria. International Journal of Financial Research, 2(2), 60-72.

Olusanmi, O., Uwuigbe, U., \& Uwuigbe, O. R. (2015). The effect of risk management on bank's financial performance in Nigeria. Journal of Accounting and Auditing: Research \& Practice, 127. 
Saeed, M.S., \& Zahid, N. (2016). The Impact of Credit Risk on Profitability of The Commercial Banks. Business \& Financial Affairs, 7.

Sun, C., \& Chang, X. (2018). The Impact of Credit Risk on Profitability of Commercial Banks. Available online at: http://summit.sfu.ca/system/files/iritems1/18344/

Sayilgan, G. (2009). Determinants of Profitability in Turkish Banking Sector: 2002-2007. International Research Journal of Finance and Economic, 28, 207-214.

Shijaku, G. (2017). Does Concentration Matter for Bank Stability? Evidence from The Albanian Banking Sector. Journal of Central Banking Theory and Practice, Central Bank of Montenegro, 6(3), 67-94.

Paper submitted

Paper accepted for publishing

Paper published online
02 March 2021

16 April 2021

31 May 2021 